\title{
Conjunctive Use of Water Resources in Sustainable Development of Agriculture in Terai Nepal
}

\author{
Debi Prasad Bhattarai, Narendra Man Shakya \\ Department of Civil Engineering, Pulchowk Campus \\ Institute of Engineering, Tribhuvan University, Kathmandu, Nepal
}

Received: Feb 24, 2019

Revised: April 7, 2019

Accepted: April 10, 2019

\begin{abstract}
The need of conjunctive use of surface and ground water resources in agricultural sector arises due to the continuous increase in population and its growing demand for the production of food and fiber globally. United Nations Sustainable Development Goal 2 also targets to double the agricultural productivity to feed the growing population and ensure sustainable food production systems by 2030 . The conjunctive uses allow the utilization of ground water and surface water simultaneously as per the demand and supply requirement of available water resources. This paper presents an overview of the conjunctive use practices in the different parts of the world in general and specific issues for conjunctive use of irrigation for sustainable agriculture in the Terai region of Nepal. It covers a synopsis of literatures available regarding the conjunctive use of irrigation system in different irrigation command area of Nepal and unveils some research issues that need to be addressed. The review also covers an overview of different computer based models developed for the management of conjunctive water use for irrigated agriculture. Based on the review conclusions are drawn which could be helpful for further research and for the management of conjunctive irrigation system in the Terai region of Nepal.
\end{abstract}

Kew words: Conjunctive use, sustainable development, agriculture, water resource

\section{Introduction}

The world population is growing continuously and is expected to reach 9.8 billion in 2050 [38]. In order to meet the food requirements of a growing population, the agricultural sector is facing a challenge to increase the food production by 60 percent by $2050[1,5]$. The issue become more critical due to urbanization, migration and industrialization, along with increases in production and consumption which have generated ever-increasing demands for freshwater resources. United Nations' Sustainable Development Goal 2 (SDG2) also targets to double the agricultural productivity to feed the growing population and ensure sustainable food production systems and implement resilient agricultural practices that increase productivity by 2030 [31]. The provision of sustainable irrigation facility is vital to achieve such target and to obtain the food security for future generation. This is possible through supply management by developing new water resource projects or efficient management of available water resources. In this regard, the conjunctive use of water resources is being considered as an important water management practice to deal with increasing irrigation demand and inadequate surface supplies. Agriculture is the largest consumer of 
the earth's available freshwater and consumes over 70 percent of the global freshwater withdrawals [12]. The sustainability of water resources largely depends on the proper management and efficient utilization of agricultural water [32]. Irrigated agriculture represents 20 percent of the world's total cultivated land, but contributes 40 percent of the total food production $[12,5]$. Irrigation is vital in achieving food security and its share in world food production will rise even in the future. However, due to availability of limited fresh water in many parts of the world, the increasing agricultural land will face water scarcity for irrigation [17]. The conjunctive use of surface and ground water can help water managers in optimum allocation plans of water resources to enhance the overall benefits from agricultural activities and can solve the problem of water shortages $[9$, 19]. It acts as a risk aversion system against the uncertainty in rainfall, waterlogging, salinity and at the same time more area can be put under cultivation with significant saving of surface supplies $[16,15]$.

\section{Development of Conjunctive Use Management Practice}

Until the late fifties, planning, management and development of surface and groundwater were dealt separately, as if they were unrelated systems. Todd [37] has first defined the conjunctive use as the integrated utilization of surface and ground water between competing sectors through basin-wise strategies. From 1960 onwards, the conjunctive use is considered as an important water management practice to increase the crop yield by providing reliable supply when a single source of water is inadequate over time and space to meet the crop water requirement. It helps in preventing water logging, salinity of soil and can reduce drainage needs [10,26].

Many researchers have also evaluated the conjunctive use of both sources in water scarce semi-arid and arid regions on the basis of economic, food security, water use efficiency and environmental concern [28]. The integrated system, if correctly managed, will yield more water at more economic rates than separately managed surface and groundwater systems [11,30]. Basagaoglu and Marino [2] developed a coupled simulation-optimization model to determine the optimal operation of both surface and ground water sources in wet and dry periods, considering the possibilities of storing the surplus water in the wet periods for use in the subsequent dry periods. Pulido-Velazquez et al. [30] explored the economic and reliability benefits from different conjunctive use alternatives for southern California's water supply system by using a flow optimization model, CALVIN and found that conjunctive use facilities and groundwater storage capacity can generate substantial economic benefits to the region. Montazar et al. [19] has explored an optimal allocation plan of both surface and ground water sources and the results indicated that conjunctive use practices are feasible and can be easily implemented in the arid command area of Qazvin Irrigation, Iran, which would enhance the overall benefits from cropping activities. Singh and Panda [36] developed an optimization model for the optimal allocation of land and water resources in order to maximize net annual returns from an irrigated area located in Haryana, India. Under the optimal land and water allocation, the groundwater use is increased, which in turn mitigate the waterlogging and salinity problems of that area.

\section{Conjunctive use for sustainable agriculture in Terai, Nepal and Research Issues}

Nepal is ranked among the richest country in terms of water resource availability. Significant proportion of water resources is distributed throughout the country in the form of different water bodies; glaciers, snow covers, rivers, springs, lakes and groundwater. There are more than 6000 
rivers including rivulets and tributaries in Nepal with drainage density of about $0.3 \mathrm{~km} / \mathrm{km}^{2}$ with a cumulative length of $45,000 \mathrm{~km}$ [3]. The distribution of rainfall in Nepal is extremely uneven in time and space, annual precipitation increases from $1200 \mathrm{~mm}$ in the foothills to $3500 \mathrm{~mm}$ and higher on the southern slopes of the high Himalayan range [34]. However, approximately 60-85 percent of annual runoff of all river systems in Nepal occurs during the three months rainy period from July to September $[8,29]$. Therefore, shortages of surface water supplies in dry season necessitate the development of groundwater in many canal commands areas. The hydro-geological mapping of Nepal also indicates that the Terrain has a tremendous potential of groundwater resources. Groundwater recharge at specific area is estimated to be as high as $600 \mathrm{~mm}$ per annum; however, it is assumed that overall $450 \mathrm{~mm}$ is a recoverable recharge figure for all of the terrain area. It is, thus, estimated that rechargeable groundwater in the Terai is anywhere between 5.8 -11.5 Billion Cubic Meter [20].

Terai consist of about 20 percent of country's total area with elevations below $300 \mathrm{~m}$ from mean sea level. The total cultivable area is about four million hector in Nepal out of which 34 percent lies in the Terai $[4,23]$. The geomorphic unit of Terai, northern edge of Gangatic Plain, is extended from $20 \mathrm{~km}$ to $50 \mathrm{~km}$, altitudes ranges from 100 to 300 meter from mean sea level and consist of alluvial coarse gravels in the north near the foothill of the mountains and gradually becoming finer towards southward [39]. Based on the preliminary hydrogeological studies unconsolidated loose sediments of Terai and inner Terai, karstified and fractured carbonate rocks of midland and Tethys group has developed good potential source for groundwater [35]. Groundwater occurs under both confined and unconfined conditions [21]. According to Onta [21] the groundwater abstractions in the aquifers are less than 20 percent of the total estimated recharge of 5,800 million cubic meters (MCM). Heavy monsoon precipitation and year-round snow-fed river systems recharge the Terai sediments, giving them a high potential for ground water resources. The aquifer system is highly sensitive to precipitation [13]. According to National Water Plan-Nepal [20], it is estimated that about $756 \mathrm{MCM}$ of groundwater resources are being used for irrigation purposes and $297 \mathrm{MCM}$ for domestic uses in Terai. Hence, there is a huge potential of groundwater use in different sector. However, none of the irrigation system in the country have so far formulated clear-cut operational plan for conjunctive use in any irrigation command area or projects though some attempts through research and extension agencies have been undertaken and developed in the country.

Groundwater occurs in unconfined shallow aquifers of 50 meters below ground level (mbgl) and under semi-confined to leaky confined deeper aquifers of $450 \mathrm{mbgl}$ [13]. According to Shrestha et al. [34] about 22 percent of the available dynamic groundwater recharge in Terai is being utilized. The transmissivity value of the shallow aquifer in the Terai region ranges from less than 10 to over $10,000 \mathrm{~m}^{2}$ /day [25]. Therefore ground water is the best alternative source of water supply in Terai region [34]. Realizing this fact, Government agencies has been developing ground water as a source of irrigation in some districts of Terai from past 30 years, but attempts are not made to treat both surface and ground water in a planned conjunctive way. Utilizing surface water in wet season and the available groundwater in the subsequent dry season in an optimized way will help to meet the crop water requirement and increase the agricultural productivity. Similarly, blending and cyclic use of different qualities of surface and groundwater may help to improve the quality and quantity of agricultural water [36, 10]. Thus there is a wide scope of using ground water in an integrated system that will yield more water at more economic rates than separately managed surface and groundwater systems. 


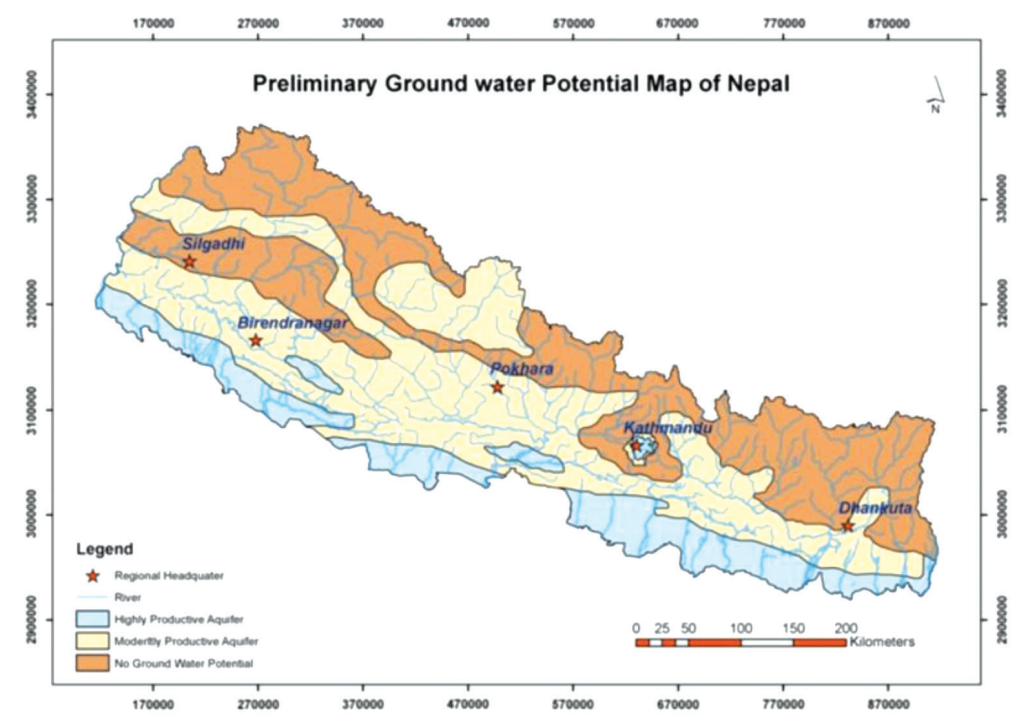

Fig. 1: Ground Water potential map (Modified after Grimmelmann, 1984)

Most of the irrigation systems in Terai, developed so far are fed by medium or small rivers, which almost entirely depend on the rainfall. Nearly 80 percent rainfall occurs during the monsoon months of June-September. This also means that 70-75 percent of the total annual flows in the rivers occur during this period [4]. According to Biswas [4], 20 percent of the land in the Terai is under perennial irrigation. Thus, about 80 percent of irrigable land in Terai depends on supplementary nature of irrigation. Since most of the irrigation system in Terai depends on monsoonal rainfall with spatial and temporal variation characteristics, water use efficiency and agricultural productivity remain low in these regions of Indo-Gangatic Plain [6]. Among others most common threats to the sustainability of agriculture in this region is recognized as depletion of ground water level, salinity and water logging and pollution of water resources [27].

\section{Way Forward}

Conjunctive use of Surface and ground water irrigation in a planned way is relatively a new practice in Nepal. However, some literatures on planning models and optimization techniques have been developed both at river basin level and farm level of irrigation command area of Terai region. Paudyal and Gupta [24] have developed an algorithm to solve the multilevel linear programming model for optimizing the integrated use of surface and ground water resources for irrigation in Tinau river basin. Onta et al. [22] developed a stochastic dynamic programming model to derive operating policy guidelines for system design capacities of ground and surface water for water allocation policy in Bagmati irrigation command area. In a study, Shah et al. [33] have found that the benefits of groundwater irrigation are widely recognized in south Asia including Terai region of Nepal, however there is less concern about its sustainability due to depletion of groundwater table and deterioration of water quality due to unregulated withdrawal. Farmers are more concerned on high energy cost for ground water withdrawal and unreliable electricity supply than falling water tables or salinity issues. 
From the literature review mentioned above, the importance and benefits of the conjunctive use of surface and ground water is well established for sustainable agricultural development in Terai region. These benefits accrue because of the different nature of the resources. Surface water has usually lower delivery and extraction costs, but is subject to variability in supply. Ground water can be expensive to pump but has a reliable supply. In either case, the conjunctive use of the two sources can decrease the risk associated with irrigation water supply in Terai. Although, Conjunctive use has been practiced in some form or the other, it has not been done in a planned manner. Therefore it is necessary to evaluate various operational policies of conjunctive water use for maximization of benefits. Such studies using optimization model for the examination of various water allocation options in a conjunctive use system are lacking in Nepal. However, in recent years few researchers have initiated such studies in some irrigation command areas of Terai.

Solutions of conjunctive management problems may not be achieved using either simulation or optimization approach alone because these approaches address different questions. Onta et al. [22] developed a multistep planning model, which used a stochastic dynamic programming and a simulation for evaluating efficient conjunctive use plans with a fixed demand (in terms of fixed cropping pattern). In this work, and many other research works, the ground water availability was considered as a fixed quantity based on the assessment using the average ground water level over the different periods of time and trying to determine the optimal combination of surface and ground water use. In real situation, the water level varies; therefore suitable pumping strategies need to be developed with respect to these variations.

While planning a surface water irrigation project in the country, the behavior and interaction of ground water has never been considered. Because optimizing the ground water in changed dynamics along with surface water can only obtain maximum net benefit at an optimal cropping pattern under various physical and economic conditions. It is necessary to identify and evaluate options using appropriate simulation/optimization models for the conjunctive management of ground and surface water resources and augmenting groundwater recharge by increasing the supply to groundwater or decreasing groundwater withdrawals. Similarly models can be develop for crop growth and water-use to identify the areas of intervention for improving water-use efficiency in different water supply situations.

Conjunctive use planning has a great scope for optimum utilization of both the surface and ground water resources. In most of the surface irrigation system, farmers in head end reaches of canal receive more canal water than those in tail end reaches. In turn, tail end farmers have to pump more ground water which leads to over extraction of ground water resources due to which the existing water table depletes. Conjunctive use of irrigation has not been practiced in a planned manner although both sources are independently used in some form or the other in the Terai region of the country. Optimization-simulation model will develop various operational policies for both head and tail reach command area for maximization of benefits. Such studies of various water allocation options are lacking in the country. Farmers cropping choices in conjunctive-based irrigated agriculture need more thorough analysis in the context of agricultural productivity and other economic, social and physical factors.

Researchers have developed different programming techniques for optimization model for the conjunctive water use during the last five decades $[9,36]$. Optimization model is a type of mathematical model that attempts to optimize (maximize or minimize) an objective function 
without violating resource constraints. The optimization model answers what is the best under a specific set of conditions. The applications of different programming techniques for the conjunctive use of different water sources are grouped into four categories: linear programming, nonlinear programming, dynamic programming and genetic algorithms.

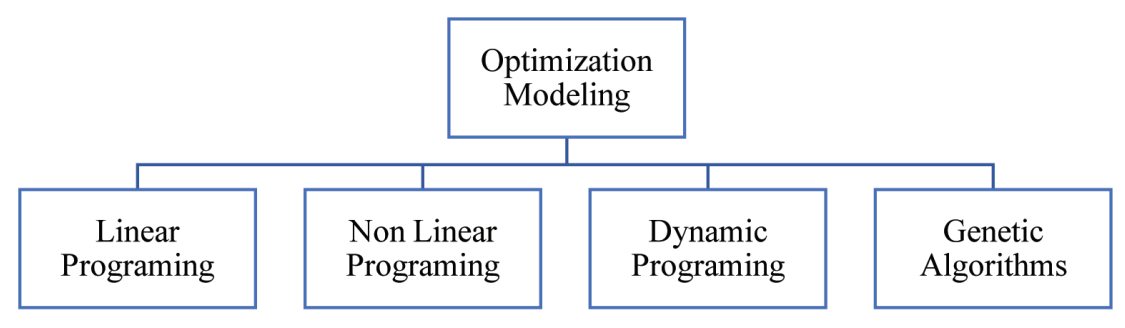

Fig. 2: Types of optimization modeling program

Simulation or optimization techniques used separately may not solve conjunctive management problems in a proper way because these techniques address different issues [36]. Optimization produces only one solution and the problem is not too complex whereas simulation can resolve more complex and realistic issues. Therefore the combined use of simulation and optimization is essential to solve conjunctive management problems [31]. Mohan and Jothiprakash [18] used a combined optimization-simulation model to develop and evaluate the alternate prioritybased policies for operation of surface and groundwater resources. They first used an LP-based management model for achieving the optimal cropping pattern with and without the conjunctive use, and then a simulation model was used to evaluate the conjunctive operation of the system using the optimal cropping pattern.

\section{Conclusions}

Water is becoming a scarce resource due to the growing need between different sectors. Water shortage problem in agricultural sector can be addressed to some extent by the conjunctive use of surface and ground water resources. The literature review reveal that conjunctive use not only increase the crop production but also controls the ground water table rise by extracting more ground water. This review paper also highlights the scope of conjunctive uses of irrigation water for sustainable irrigated agriculture in Terrain due to its high recharge capacity, fertile land and availability of surface water as well. Different computer based management models have been used for the optimization of conjunctive water use for agriculture. The combined use of optimization -simulation has been recently preferred for solving the conjunctive water management problems because the optimal solutions may not be achieved using either simulation or optimization technique alone. Terai region of Nepal has options or combination of options that may be pursued so that substantial growth in agricultural production can be generated, which will be more than keep pace with population growth as well as contribute surpluses for export. The fertile farmland of Terai which is popularly known as "Anna Bhandar" (food store) of the country will be benefited by conjunctive irrigation system. 


\section{References}

[1] Alexandratos N and Bruinsma J (2012), World agriculture towards 2030/2050: the 2012 revision, 12(3), FAO, Rome: ESA working paper.

[2] Basagaoglu H and Mariňo MA (1999), Joint management of surface and ground water supplies, Groundwater, 37(2): 214-222.

[3] Bhattarai D (2009), Multi-purpose projects, In The Nepal-India Water Relationship: Challenges (pp. 69-98), Springer, Dordrecht.

[4] Biswas AK (1989), Irrigation in Nepal: Opportunities and constraints, Journal of irrigation and drainage engineering, 115(6): 1051-1064.

[5] Bruinsma J (2017), World agriculture: towards 2015/2030: an FAO study. Routledge.

[6] Cassman KG and Pingali PL (1995), Extrapolating trends from long-term experiments to farmers' fields: the case of irrigated rice in Asia.

[7] Castle EN and Lindeborg KH (1960), The Economics of Ground Water Allocation: A Case Study, Journal of Farm Economics, 42(1): 150-160.

[8] Chaulagain NP (2003), Impacts of climate changes on water resources of Nepal, A case study of Tsho Rolpa glacial lake, MSc. thesis SESAM, International Institute of Management, University of Flensburg, Germany.

[9] Cheng Y, Lee CH, Tan YC and Yeh HF (2009), An optimal water allocation for an irrigation district in Pingtung County, Taiwan, Irrigation and Drainage: The journal of the International Commission on Irrigation and Drainage, 58(3): 287-306.

[10] Coe JJ (1990), Conjunctive use - advantages, constraints, and examples, Journal of irrigation and drainage engineering, 116(3): 427-443.

[11] Draper AJ, Jenkins MW, Kirby KW, Lund JR and Howitt RE (2003), Economic-engineering optimization for California water management, Journal of water resources planning and management, 129(3): 155-164.

[12] FAO (2017), Water for Sustainable Food and Agriculture: A report produced for the G20 Presidency of Germany, Food and Agricultural Organization (FAO), Rome.

[13] Gurung I (2005), Geological and geochemical examination, Springer: pp. 4-5

[14] Hamdy A, Ragab R and Scarascia-Mugnozza E (2003), Coping with water scarcity: water saving and increasing water productivity, Irrigation and drainage, 52(1):3-20.

[15] Kazmi SI, Ertsen MW and Asi MR (2012), The impact of conjunctive use of canal and tube well water in Lagar irrigated area, Pakistan, Physics and Chemistry of the Earth, Parts A/B/C, 47: 8698.

[16] Khare D and Jat MK (2006), Assessment of conjunctive use planning options: A case study of Sapon irrigation command area of Indonesia, Journal of Hydrology, 328(3-4): 764-777.

[17] Mancosu N, Snyder RL, Kyriakakis G and Spano D (2015), Water scarcity and future challenges for food production, Water, 7(3): 975-992.

[18] Mohan S, and Jothiprakash V (2003), Development of priority-based policies for conjunctive use of surface and groundwater, Water international, 28(2): 254-267.

[19] Montazar A, Riazi H, Behbahani SM (2010), Conjunctive water use planning in an irrigation command area, J Water Resour Manage 24:577-596

[20] National Planning Commission. (2002), The Tenth Plan, Government of Nepal, Kathmandu.

[21] Onta IR (2004), State of Nepals' Water, Research Report, Third World Center for Water Management, The Nippon Foundation,Kathmandu, Nepal.

[22] Onta PR, Gupta AD and Harboe R (1991), Multistep planning model for conjunctive use of surface- 
and ground-water resources, Journal of Water Resources Planning and Management, 117(6): 662-678.

[23] Pariyar MP (2003), Water and poverty linkages in mountainous areas: a case study from Nepal, Water and poverty linkages: case studies from Nepal, Pakistan and Sri Lanka, International Water Management Institute, Sri Lanka: 5-50.

[24] Paudyal GN and Gupta AD (1990), Irrigation planning by multilevel optimization, Journal of Irrigation and Drainage Engineering, 116(2): 273-291.

[25] Pavelic P, Shrestha SR, Zahid A and Saha D (2016), Groundwater resources, In The Ganges River Basin (pp. 58-85), Routledge.

[26] Petheram C, Bristow KL and Nelson PN (2008), Understanding and managing groundwater and salinity in a tropical conjunctive water use irrigation district, Agricultural water management, 95(10): 1167-1179.

[27] Pingali PL and Shah M (1999), Rice-wheat cropping systems in the Indo-Gangetic Plains: Policy redirections for sustainable resource use, Sustaining rice-wheat production systems: Socio-economic and policy issues, Rice-Wheat Consortium Paper Series, 5: 1-12.

[28] Portoghese I, Uricchio V and Vurro M (2005), A GIS tool for hydrogeological water balance evaluation on a regional scale in semi-arid environments, Computers \& Geosciences, 31(1): 1527.

[29] Pradhan PMS (2004), Improving sediment handling in the Himalayas, OSH research, Nepal.

[30] Pulido-Velázquez M, Andreu J and Sahuquillo A (2006), Economic optimization of conjunctive use of surface water and groundwater at the basin scale, Journal of Water Resources Planning and Management, 132(6): 454-467.

[31] Rasul G (2016), Managing the food, water, and energy nexus for achieving the Sustainable Development Goals in South Asia, Environmental Development, 18:14-25.

[32] Schoups G, Addams CL, Minjares JL and Gorelick SM (2006), Sustainable conjunctive water management in irrigated agriculture: Model formulation and application to the Yaqui Valley, Mexico, Water Resources Research, 42(10).

[33] Shah T, Singh OP and Mukherji A (2006), Some aspects of South Asia's groundwater irrigation economy: analyses from a survey in India, Pakistan, Nepal Terai and Bangladesh, Hydrogeology Journal, 14(3): 286-309.

[34] Shrestha AB, Wake CP, Dibb JE and Mayewski PA (2000), Precipitation fluctuations in the Nepal Himalaya and its vicinity and relationship with some large scale climatological parameters, International Journal of Climatology, 20(3): 317-327.

[35] Shrestha SR, Tripathi GN and Laudari D (2018), Groundwater Resources of Nepal: An Overview. In Groundwater of South Asia (pp 169-193), Springer, Singapore.

[36] Singh A and Panda SN (2012), Development and application of an optimization model for the maximization of net agricultural return, Agricultural water management, 115: 267-275.

[37] Todd DK (1959), Ground water hydrology, John Wiley and Sons, Inc, New York.

[38] United Nations (2013), World population prospects: the 2017 revision-key findings and advance tables, United Nations Population Division.

[39] Upreti BN (1999), An overview of the stratigraphy and tectonics of the Nepal Himalaya, Journal of Asian Earth Sciences, 17(5-6): 577-606. 